Article

\title{
Integrating Human Rights and the Environment in Supply Chain Regulations
}

\author{
Almut Schilling-Vacaflor
}

check for

updates

Citation: Schilling-Vacaflor, A. Integrating Human Rights and the Environment in Supply Chain Regulations. Sustainability 2021, 13, 9666. https://doi.org/10.3390/ su13179666

Academic Editors:

Olga Martin-Ortega, Valerie Nelson, Renginee G. Pillay and

Fatimazahra Dehbi

Received: 27 July 2021

Accepted: 23 August 2021

Published: 27 August 2021

Publisher's Note: MDPI stays neutral with regard to jurisdictional claims in published maps and institutional affiliations.

Copyright: (C) 2021 by the author. Licensee MDPI, Basel, Switzerland. This article is an open access article distributed under the terms and conditions of the Creative Commons Attribution (CC BY) license (https:// creativecommons.org/licenses/by/ $4.0 /)$.
Institute of Social Sciences, University of Osnabrück, 49074 Osnabrück, Germany; aschillingva@uni-osnabrueck.de

\begin{abstract}
To address the negative externalities associated with global trade, countries in the Global North have increasingly adopted supply chain regulations. While global supply chains cause or contribute to interconnected environmental and human rights impacts, I show that supply chain regulations often exclusively target one policy domain. Furthermore, an analysis of the first experiences with the implementation of the French Duty of Vigilance law, which covers and gives equal weight to environmental and human rights risks, reveals that the inclusion of environmental and human rights standards in legal norms is not sufficient to ensure policy integration. The empirical focus here is on the soy and beef supply chains from Brazil to the European Union (EU), and the findings rely on an analysis of legal norms and company reports, field research at producing sites in Brazil and semi-structured interviews with civil society, business and state actors. For analyzing the data, I draw on the literature on environmental policy integration (EPI) and apply a framework that distinguishes between institutional, political and cognitive factors to discuss advances and challenges for integrating human rights and the environment in sustainability governance. The study concludes that more integrated approaches for regulating global supply chains would be needed to enable 'just sustainability'.
\end{abstract}

Keywords: policy integration; global supply chains; business and human rights; environmental governance; Sustainable Development Goals (SDGs); due diligence; policy-making; corporate accountability; soybeans; cattle; deforestation; land rights; Brazil; European Union (EU)

\section{Introduction}

Global supply chains have gained further importance over the past few decades, spanning over distant continents and places with the aim of supplying goods and services. In line with the definition by the International Labor Organization (ILO), my understanding of global supply chains includes multinational enterprises and their subsidiaries or joint ventures, as well as international sourcing from suppliers and subcontracted firms [1]. While transnational corporations, which nowadays already account for half of global exports and about one fourth of global employment, play a dominant role in global supply chains, many small and medium enterprises are also involved in global production networks [2].

Our global economy and the consumption patterns especially in countries of the Global North and in emerging economies have increasingly relied on global supply chains, whose environmental and human rights impacts have comprehensively been discussed in the scholarly literature [3-5]. The negative externalities of global trade have largely concentrated on the sites of production or extraction, often located in the Global South. At the same time, global production networks and the activities of multinational enterprises have been key drivers of global environmental problems such as climate change and biodiversity loss. For instance, Rajão et al. found that at least $18 \%$ of soy imports and approximately $48 \%$ of beef imports from Brazil to Europe have likely been associated with illegal deforestation, which has contributed to substantial amounts of global greenhouse 
gas emissions [6]. Soy and beef supply chains from Brazil have also caused or contributed to human rights violations, due to a loss of local communities, family farmers and indigenous peoples' access to land, water and livelihoods; negative health impacts in consequence of pesticide pollution and poisoning; and violence against the defenders of lands and the environment [7-11]. As outlined below, human rights and environmental concerns have been interconnected in soy and beef supply chains in Brazil, as well as in the supply chains of other goods and commodities such as palm oil, metals or fossil fuels.

Current governance arrangements have been insufficient to regulate global supply chains and to hold corporations accountable for their human rights and environmental performance beyond the borders of their home states [12-14]. There has been an absence of related international conventions or treaties and the shortcomings of private and voluntary approaches such as certification standards and corporate commitments have become ever more evident $[15,16]$. In turn, domestic policies in the producing countries have often been inappropriate for protecting the environment and human rights from the negative externalities of globalized business activities [6,17]. Against this background, transnational companies have largely enjoyed legal impunity for the negative impacts caused by their subsidiaries or suppliers or even benefitted economically from exploitative or environmentally damaging business relationships. In response to existing governance gaps and fostered by pressure from civil society, as well as in some cases supported by domestic industries to increase their competitiveness, countries in the Global North have adopted or are currently discussing the adoption of mandatory rules to regulate their supply chains [18-20]. The European Union (EU) is not only the largest trading block in the world, but it has recently also been at the forefront of adopting supply chain regulations [21,22].

With reference to the United Nations (UN) Protect, Respect and Remedy framework and the UN General Principles on Business and Human Rights (UNGPs) adopted in 2011, new supply chain regulations tend to build on a mandatory due diligence (MDD) approach. While the UNGPs do not explicitly refer to environmental standards, to differing extent some of the new MDD laws have integrated environmental issues. This is why the term 'human rights due diligence (HRDD)' has more recently increasingly been reframed as 'human rights and environmental due diligence (HREDD)' in policy discourses [23]. However, an analysis of the extent to which supply chain regulations actually integrate both policy domains, human rights and the environment is still missing. This study aims to fill this research gap. In addition, this article also explores the advances and challenges of policy integration in the implementation phase of new MDD laws, with a focus on the French Duty of Vigilance (DV) law, adopted in 2017, which has included both environmental and human rights issues to the largest extent to date. Empirically, this study centers on the soy and beef supply chains from Brazil to Europe, which are critical cases, not only because of the large volumes traded but also due to the severe environmental and human rights impacts associated with these sectors.

The study finds that most laws regulating supply chains have not yet properly included environmental and human rights protection and thus fail to address many of the negative impacts associated with the cattle and soy sectors in Brazil. Furthermore, the analysis of the implementation of the DV law reveals that the institutionalization of policy integration on paper is insufficient, as diverse political and cognitive factors have contributed to weak policy integration in due diligence systems of French companies. The study concludes that more integrated approaches for regulating global supply chains would be needed to enable 'just sustainability', understood as "to ensure a better quality of life for all, now, and into the future, in a just and equitable manner, while living within the limits of supporting ecosystems" [24] (p. 2).

After briefly reviewing the literature on policy integration, with a focus on the environment and human rights (Section 2), I describe my methods of data collection and analysis (Section 3). In Section 4, I first provide important information about the environmental and human rights impacts of soy and beef production in Brazil and their interaction. 
Then, I analyze to what extent supply chain regulations from the EU and Member States include environmental and human rights standards and cover the impacts identified in the Brazilian cattle and soy sectors. Thereafter, I discuss the due diligence systems of French companies involved with soy and beef from Brazil, with a focus on the disarticulated way in which they have addressed environmental and human rights concerns. The discussion and conclusions follow.

\section{Policy Integration of the Environment and Human Rights}

The concept of policy integration and related analytical frameworks have previously mainly been applied to environmental policy integration (EPI) in the EU and Member States, to climate policy integration and to the integration of conflicting policy goals in the process of drafting and implementing the SDGs. By contrast, as outlined in the introduction, this study centers on the question to what extent policy integration between human rights and the environment can be observed in new regulatory approaches targeting global supply chains and discusses the related advances and challenges with reference to supply chains from Brazil.

Collier defined policy integration as "removing contradictions between policies as well as within policies; and realizing mutual benefits and the goal of making policies mutually supportive" [25] (p. 36). As Biermann et al. convincingly argued, the distinction between internal integration (the integration within one policy domain) and external integration (the integration across different policy domains) is important, because fragmentation within one policy domain often also constitutes a major problem [26].

The need to better connect the goals of economic competitiveness, social development and environmental protection in order to achieve sustainable development has been highlighted in the 1987 Brundtland Report [27]. Lafferty and Hovden even argued that the Brundtland Report attributed 'principled priority' to environmental objectives, thereby ensuring that "the long-term carrying capacity of nature becomes a principal or overarching societal objective" [28] (p. 9). However, such a strong (i.e., pro-environment) reading of EPI has co-existed with weaker interpretations that have understood policy integration as better coordination between different but equally weighed policy objectives [29].

The specific link between the environment and human rights was acknowledged in the Rio Declaration on Environment and Development from 1992. Since 2012, the UN have also appointed a Special Rapporteur on human rights and the environment. Similarly, pointing into the direction of increased policy integration, the Sustainable Development Goals (SDGs) have been praised for their special attention to the interlinkages between the various dimensions of sustainability. Indeed, one of the targets of the SDGs is the achievement of policy coherence between the different interdependent goals as a necessary condition for sustainable development [30]. The particularly close inter-relation between human rights and the enjoyment of a safe, clean, healthy and sustainable environment has also been outlined in the 'Framework Principles on Human Rights and the Environment' from 2018. The principles state: "Human beings are part of nature, and our human rights are intertwined with the environment in which we live. Environmental harm interferes with the enjoyment of human rights, and the exercise of human rights helps to protect the environment and to promote sustainable development" [31] (p. 5).

Despite the increased recognition of the close links between the environmental and social dimension for attaining sustainable development, empirical studies have shown that policy integration in the implementation of the SDGs at the national level has strongly depended on domestic policy-making processes, actor constellations and institutional preconditions [30,32]. Siegel and Bastos Lima further found that in contradiction to the idea of policy integration, political and economic actors often employ a cherry-picking approach of preferred goals or targets as a sign of supposed adherence to the whole 2030 Agenda [32]. Merino and Gustafsson show that fragmented interventions that have prioritized either environmental or human rights issues have reinforced conflicts and inequality in the Peruvian Amazon, and ultimately undermined both social and environmental sus- 
tainability [33]. Relatedly, with a focus on the field of business and human rights, Dehbi and Martin-Ortega found that limited consideration has been given to the environment and that policy integration in this area has been approached in an "ad hoc and piecemeal manner" [34]. The above-mentioned findings sustain Jordan and Lenschow's argument that the support of the principle of policy integration is insufficient for overcoming the challenge that policy-making processes and policy implementation are often carried out in fragmented and siloed ways [29].

For explaining stronger, respectively weaker, policy integration, I draw on Jordan and Lenschow's analytical framework, which distinguishes between (1) institutional, (2) political and (3) cognitive factors [30].

First, as policy integration relies on cross-sectoral and multi-level coordination, more coordinated organizational structures and procedures are needed, both horizontally and vertically [35]. Institutional contexts, thus, can be more or less appropriate for enabling processes of policy integration. The drafting and institutional design of policies on the one hand and their implementation and outcomes on the other are closely interlinked, and both stages are equally important for explaining the effectiveness of policies (and policy integration) [12]. Institutional contexts not only differ with regards to their degree of fragmentation but also with regards to the existence of norm conflicts. Biermann et al. distinguish between "cooperative fragmentation" and "conflictive fragmentation" [36]. The first refers to a situation in which an issue is addressed by several different institutions that are loosely integrated, but there are no conflicting objectives between these institutions. In a situation of conflictive fragmentation, by contrast, issues are governed by largely unconnected institutions with conflicting norms, principles and rules.

Second, policy integration is a dynamic process that relies on the support of political actors and institutions. With this regard, power asymmetries between different political forces and related interests as well as coalition-building can be decisive for the extent to which policy integration is attained in the institutional design and implementation of different policies and objectives. For instance, in the case of MDD laws emerging in Europe, left-wing and green parties have often pushed for more stringent and comprehensive rules, while liberal, conservative and right-wing parties have tended to support rules that are weak and narrow in their scope [22]. Moreover, with regard to the political and interest dimension of policy integration, Nilsson and Persson found that policy issues with high conflict potential have generally been characterized by lower levels of policy integration, "because when core values are at stake on an issue, actors are not willing to interact" [37] (p. 345).

Third, cognitive approaches such as ideas and discourses expressed by non-state actors such as NGOs, the media or experts can induce social learning and shape both policy processes and institutional frameworks [38]. For instance, the generation and dissemination of scientific knowledge to negotiators or the raising of awareness of specific (environmental or human rights related) discourses in national or international debates can foster, or respectively hinder, policy integration [26]. With regard to cognitive factors, scholars also emphasized that policy integration depends on the problem characteristics, as problems for which the knowledge base is uncertain or contested are expected to have lower levels of policy integration [37,39]. Nilsson and Persson explain that "when facts are uncertain, actors can challenge every bit of information and will do so if they gain from

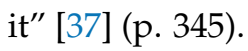

In what follows, Section 4.2 analyzes the content of supply chain regulations and centers on institutional pre-conditions for policy integration, while Section 4.3 mainly relates to political and cognitive factors for explaining policy (dis)integration.

\section{Materials and Methods}

For analyzing the institutional design of supply chain regulations, I first analyzed all laws targeting environmental and human rights impacts in supply chains from the EU level and Member States. When coding these documents, I focused on the question of 
which human rights and environmental standards and issues they cover, in order to assess the extent to which they enable an integration of human rights and the environment.

The empirical data for the case study on environmental and human rights impacts of the soy and cattle sectors in Brazil were collected during different field research periods of a total of four months carried out between June 2017 and March 2020. As part of these research stays, I conducted seventy-two semi-structured interviews with soy and beef producers, business associations, state actors from different institutions (e.g., Ministry of Agriculture, Ministry of the Environment, Public Prosecutor's Office, deputies from the Brazilian Congress, Brazilian Forest Service, Brazilian Institute of Environment and Renewable Natural Resources IBAMA) and non-state actors, including national and transnational environmental and human rights NGOs, grassroots organizations, family farmers, indigenous peoples and Quilombola (i.e., Afro-Brazilian) communities and rural workers' unions. To discuss my research findings, together with colleagues, I also organized a multi-stakeholder workshop with Brazilian scholars and environmental and human rights organizations in March 2020 [40].

To gain a better understanding of the design and implementation of supply chain regulations, I conducted 18 interviews with environmental and human rights NGOs, experts and staff from state agencies working in Brussels, France, Germany and Switzerland and analyzed French company reports on their due diligence systems. The great majority of interviews were recorded with the consent of the interviewees, but in some cases written notes were taken instead. I anonymized interviews and translated data cited in this paper to English.

\section{Results}

In this empirical section, I first outline important human rights and environmental impacts and their interconnection in Brazil's soy and cattle sectors. Then I analyze to what extent supply chain laws at EU and Member State level include environmental and human rights standards. Thereafter, I present new findings on policy (dis)integration in the implementation of the French DV law.

\subsection{Environmental and Human Rights Impacts and Their Interaction in Brazil's Soy and Beef Supply Chains}

Brazil has become a leader of global exports of agro-commodities such as soybeans and bovine meat. Soy and beef from Brazil have together accounted for the majority of imported deforestation in Europe [41]. In the following section, I outline that human rights violations and instances of environmental degradation in some occasions have occurred separately in these sectors, while many times these impacts have been interconnected, and there have also been trade-offs between environmental and human rights protection. To simplify these patterns of interaction, I distinguish between type 1 impacts (either environmental or human rights impacts), type 2 impacts (interconnected environmental and human rights impacts) and type 3 impacts (trade-offs between environmental and human rights impacts) (see Table 1). Furthermore, I argue that in particular type 2 and type 3 impacts require integrated governance responses to be addressed effectively.

Type 1 impacts: Human rights infringements such as the violation of labor rights or of civil and political rights are often de-coupled from environmental problems and, therefore, do not require integrated approaches. An example of such impacts are the 1160 instances of modern slavery formally registered in Brazil between 2011 and 2020 (whereby the number of unreported cases is much higher); most of them occurring in the cattle sector (432 cases) [9]. In turn, slow processes of environmental deterioration such as a continuous decrease in the levels of groundwater and river flows due to deforestation, massive irrigation for agribusiness purposes and the impacts of climate change, do not necessarily lead to immediate human rights violations. However, in the long term, type 1 impacts might turn into type 2 impacts. For instance, the decrease in water sources can lead to water insecurity and negatively affect the right to water and food [42]. Another important example from Brazil's soy sector is the intensive use of pesticides, which has not 
only polluted local environments, but also contributed to negative health impacts, such as the poisoning of thousands of Brazilian citizens [8].

Table 1. Examples of environmental (ENV) and human rights (HR) impacts and their interaction in the Brazilian case study (author's elaboration).

\begin{tabular}{|c|c|c|c|}
\hline \multicolumn{2}{|c|}{ Type 1 Impacts } & \multirow{2}{*}{$\begin{array}{c}\text { Type } 2 \text { Impacts } \\
\text { Co-Occurrence of ENV and } \\
\text { HR Impacts }\end{array}$} & \multirow{2}{*}{$\begin{array}{c}\text { Type } 3 \text { Impacts } \\
\text { Trade-Offs between ENV and } \\
\text { HR Impacts }\end{array}$} \\
\hline ENV Impacts & HR Impacts & & \\
\hline $\begin{array}{l}\text { ENV degradation without } \\
\text { immediate impacts on } \\
\text { human rights (e.g., } \\
\text { reduction of water } \\
\text { quantity and quality, } \\
\text { biodiversity loss, and } \\
\text { climate change); can turn } \\
\text { into type } 2 \text { impacts }\end{array}$ & $\begin{array}{l}\text { Labor rights (e.g., right to } \\
\text { unionize; working hours; } \\
\text { prohibition of modern slavery } \\
\text { and child labor); } \\
\text { Civil and political rights (e.g., } \\
\text { non-discrimination, right to } \\
\text { life and physical integrity) }\end{array}$ & $\begin{array}{l}\text { Deforestation contributes to } \\
\text { violations of tenure rights and } \\
\text { the right to food; } \\
\text { Pesticide contamination affects } \\
\text { the rights to health, water and } \\
\text { to a healthy ENV; } \\
\text { Violence against ENV defenders }\end{array}$ & $\begin{array}{l}\text { Legal reserves for conservation } \\
\text { purposes contribute to violation } \\
\text { of tenure rights; } \\
\text { People dispossessed from their } \\
\text { lands contribute to deforestation } \\
\text { and land use change }\end{array}$ \\
\hline
\end{tabular}

Type 2 impacts: Many of the negative externalities of Brazil's soy and beef supply chains have been associated with inter-linked environmental and human rights impacts. Deforestation and land use change in Brazil have mainly been caused by a combination of land grabbing and land speculation, the (largely illegal) logging of timber and the expansion of cattle ranching, indirectly driven by the expanding cultivation of crops such as soybeans [40-45]. The deforestation and degradation of the Amazon has attracted much scholarly and socio-political attention, as this rainforest is one of the key elements in the Earth's climate system whose dieback may trigger catastrophic climate change [45]. In a context of contested and unclear land tenure rights, deforestation in Brazil has often been used for 'grabbing' lands and has been associated with a dispossession of local communities and family farmers from their access to land and livelihoods [43,44,46]. In turn, the titling of indigenous lands has proven to be a powerful tool for preventing deforestation and forest degradation [47]. Therefore, many scholars have argued that without fundamental changes of laws regulating land tenure, the problem of deforestation cannot be resolved. Another example of the interdependence of environmental and human rights protection is the intimidation of and violence against the defenders of lands and the environment, among which are many indigenous people(s) $[9,10]$. These examples show that environmental protection is a fundamental element of a rights-based approach to development, while the enjoyment of human rights such as the right to land and to physical integrity can contribute to healthy environments.

Type 3 impacts: It is also important to acknowledge trade-offs between the goals to protect human rights and the environment. Such an acknowledgement can foster policy coherence and help to prevent or mitigate unintended consequences. For instance, in Brazil, the forest code from 2012 obliges farmers to set aside an area equivalent to $80 \%$ of their property in the Amazon and $20-35 \%$ in the Cerrado as a 'legal reserve' (Reserva Legal) for biodiversity and forest protection. At the same time, the forest code built the legal basis for the establishment of a self-declaratory rural environmental registry system called CAR (Cadastro Rural Ambiental). Concretely, this means that soy farmers must be able to prove that they have set aside a portion of their property for conservation purposes and register the agricultural land and its legal reserve in the CAR. However, as the legal reserve does not necessarily need to be adjacent of the farmer's agricultural land, in practice many farmers declare to hold conservation areas in places that are used or inhabited by local communities and family farmers who often do not possess land titles, thereby contributing to the dispossession of vulnerable actors from their lands and livelihoods $[16,46]$ (interview with Brazilian grassroots organization, 13 August 2018; interview with staff from Brazil's public prosecutor office, 17 August 2018). In turn, in many instances, displaced people end 
up at the settlement frontier, entering remaining forests, the land of Indigenous peoples or protected areas [48].

Based on this overview of the interaction between environmental and human rights impacts associated with soy and beef production in Brazil, we can draw important lessons for the design and implementation of policies that regulate global supply chains. While addressing the full spectrum of negative impacts in an integrated manner is desirable from a normative standpoint, I argue that the lack to acknowledge the interdependency of environmental and human rights impacts often undermines the effectiveness of governance approaches. More integrated norms and policies that are comprehensive in their scope and cover both environmental and human rights issues have the potential to foster synergies and pay attention to possible trade-offs between environmental and human rights impacts. In what follows, I analyze whether and to what extent supply chain regulations integrate environmental and human rights domains or whether they prioritize or selectively include only one of these domains.

\subsection{The Institutional Design of Supply Chain Regulations: Integrating the Environment and Human Rights?}

Already before the UNGPs were approved, the EU adopted supply chain regulations, mainly with the aim of addressing environmental problems. In 2008, the EU adopted a regulation to eliminate illegal, unreported and undocumented fishing (IUU Regulation) and in 2009 (revised in 2018) a directive on renewable energies (EU-RED and EU-RED II) that includes environmental sustainability criteria for forestry feedstocks and GHG criteria for solid and gaseous biomass fuels. Both legal norms, however, are narrow in their scope, as they focus only on a specific product and exclusively address environmental issues. In the drafting process of EU-RED, the inclusion of social criteria along environmental ones such as labor and land use or tenure rights was discussed but rejected in the course of the negotiations [49]. The sustainability criteria established in EU-RED are relevant for soy used as biofuel that is imported by the EU, which is, however, only a minor share of all soy being imported. The major volume of soy and soy meal imported into the EU is used as animal feed.

In 2010 (revised in 2019), the EU adopted the EU Timber Regulation (EUTR), which builds on a due diligence approach and requires operators putting timber on the internal market to present "documents or other information indicating compliance of those timber and timber products with the applicable legislation" [50]. Hence, the regulation does not require the compliance with international environmental or human rights standards, but with the laws of producer countries. This approach has been problematic in countries such as Brazil, where environmental and human rights policies have been dismantled in the recent past (interview with competent authority for the EUTR from Germany, 17 June 2020; interview with environmental NGO based in Brussels, 2 July 2019). Moreover, the focus of the EUTR is on the avoidance of illegal timber, while it deprioritizes other sustainability problems. For instance, with regard to risk assessment, the EUTR stipulates that the operator shall "analyze and evaluate the risk of illegally harvested timber or timber products derived from such timber being placed on the market" [50]. Against this background, Ituarte-Lima et al. argued that the EUTR should be better aligned with the Convention on Biodiversity (CBD) and include a human rights approach and social safeguards to ensure that local communities' access to as well as their use of and benefits from forests and forest-related resources are guaranteed [51]. The EUTR exclusively focuses on timber, but the reduction of illegal logging is also relevant for cattle production (and, more indirectly, for soy cultivation), as it could weaken the unsustainable links between deforestation, land grabbing and cattle raising in Brazil.

After the adoption of the UNGPs, most EU countries adopted national action plans (NAP) to advance the principles' implementation, but these plans have usually included exclusively voluntary measures with limited effectiveness [52]. Importantly, however, the EU and some Member States also adopted mandatory measures, which integrate environmental standards to differing extents. The former EU state United Kingdom (UK) 
adopted its UK Modern Slavery Act (2015), the EU a Conflict Minerals Regulation (2017) and the Netherlands a Child Labor Due Diligence law (2019). In line with the UNGPs, these three norms do not refer to environmental standards or issues at all. While the Conflict Minerals Regulation is not relevant for soy and beef supply chains from Brazil, the other two laws could help to address the violation of labor rights in these two chains.

By contrast, the French DV law (2017) is characterized by a particularly comprehensive scope regarding the coverage of environmental and human rights issues to be assessed and addressed by companies. The law establishes the obligations of companies "to identify risks and prevent serious violations of human rights and fundamental freedoms, the health and safety of individuals and the environment, resulting from the activities of the company and those of the companies it controls [ ... ] directly or indirectly, as well as from the activities of subcontractors or suppliers with whom there is an established business relationship" [53]. As I further outline below, several large French companies involved with soy and beef supply chains from Brazil are covered by the law and obliged to show how they assess and address all kinds of negative environmental and human rights impacts.

The German parliament adopted a supply chain due diligence law (Lieferkettensorgfaltspflichtengesetz) in June 2021, which should help to assess, prevent and mitigate human rights violations, among them environment-related human rights violations. The law covers human rights risks in a rather broad sense and includes environment-related human rights issues, stipulating: "The prohibition of causing harmful soil alteration, water pollution, air pollution, harmful noise emission or excessive water consumption, which is likely to;

(a) significantly affect the natural basis for the preservation and production of food,

(b) deny a person access to safe drinking water,

(c) impede or destroy a person's access to sanitary facilities; or

(d) harm the health of a person;

The prohibition of unlawful eviction and the prohibition of unlawful deprivation of land, forests and waters in the acquisition, construction or other use of land, forests and waters, the use of which secures the livelihood of a person" [54]. Furthermore, the German law establishes selected environmental obligations related to the use of mercury, the prohibition of the production and use of chemicals listed in the Stockholm convention and the disposal of waste. German environmental organizations criticized that the law only covers environmental damages whenever they cause infringements of human rights, instead of establishing a general obligation to protect the environment [55]. Such a general obligation to contribute to a healthy environment would have implied the coverage of all environmental impacts associated with soy and beef from Brazil, including type 1 (ENV) impacts and could help to better account for type 2 and type 3 impacts (Section 4.1). The Green Party (Bündnis 90/Die Grünen) even submitted a request to amend the law in order to strengthen its contribution to environmental protection, arguing: "The amendment enables comprehensive protection of the environmental goods soil, air, water, biodiversity and global climate in the sense of the precautionary principle $[\ldots]$. This also provides preventive protection of human rights arising from cumulative and creeping environmental degradation" [56]. However, this request was rejected in a parliamentary vote. Table 2 provides an overview of environmental and human rights issues covered by supply chain regulations and outlines their relevance for the Brazilian cattle and soy sector.

Overall, the analysis of the extent to which supply chain regulations integrate the environment and human rights revealed that the large majority of adopted laws can be characterized either as exclusively environmental or exclusively human rights norms, pointing to significant shortcomings in institutionalizing policy integration. With regard to soy and beef supply chains from Brazil, existing regulations have created a rather patchy and fragmented response to selected impacts, while neglecting others and leaving the interaction between different environmental and human rights impacts largely unaddressed. From this sample of supply chain regulations, only the German due diligence law and the French DV law establish both environmental and human rights duties. However, the German law 
was adopted recently and its implementation will start in 2023. In the following section, I present new findings on policy integration in the implementation of the DV law, which has integrated environmental and human rights issues to the broadest extent.

Table 2. Environmental and human rights issues covered in supply chain regulations (author's elaboration).

\begin{tabular}{|c|c|c|c|c|}
\hline $\begin{array}{l}\text { Supply Chain } \\
\text { Regulation }\end{array}$ & ENV Issues & HR Issues & $\begin{array}{c}\text { Policy } \\
\text { Integration? }\end{array}$ & $\begin{array}{l}\text { Relevance for Brazilian } \\
\text { Cattle and Soy Sector }\end{array}$ \\
\hline $\begin{array}{l}\text { EU IUU } \\
\text { regulation }\end{array}$ & $\begin{array}{l}\text { Marine and biodiversity } \\
\text { protection in compliance } \\
\text { with international law }\end{array}$ & - & $\begin{array}{l}\text { Exclusively } \\
\text { ENV norm }\end{array}$ & - \\
\hline $\begin{array}{l}\text { EU-RED and } \\
\text { EU-RED II }\end{array}$ & $\begin{array}{l}\text { ENV sustainability } \\
\text { criteria for forestry } \\
\text { feedstocks and GHG } \\
\text { criteria for solid and } \\
\text { gaseous biomass fuels }\end{array}$ & - & $\begin{array}{l}\text { Exclusively } \\
\text { ENV norm }\end{array}$ & $\begin{array}{l}\text { Covers only type } 1 \text { (ENV) } \\
\text { impacts related to } \\
\text { soybeans used as biofuel }\end{array}$ \\
\hline $\begin{array}{c}\text { EU Timber } \\
\text { Regulation (EUTR) }\end{array}$ & $\begin{array}{l}\text { Due diligence obligations } \\
\text { to avoid illegally } \\
\text { harvested timber } \\
\text { according to the laws of } \\
\text { the producing country }\end{array}$ & $\begin{array}{l}\text { HR only indirectly } \\
\text { included as part of the } \\
\text { legality verification }\end{array}$ & $\begin{array}{l}\text { Mainly ENV norm, } \\
\text { no explicit focus on } \\
\text { HR protection }\end{array}$ & $\begin{array}{l}\text { Mainly type } 1 \text { (ENV) } \\
\text { impacts; only indirectly } \\
\text { important due to link } \\
\text { between deforestation, } \\
\text { cattle and soy production }\end{array}$ \\
\hline $\begin{array}{l}\text { UK Modern } \\
\text { Slavery Act }\end{array}$ & - & $\begin{array}{c}\text { Due diligence } \\
\text { obligations to assess } \\
\text { and address } \\
\text { modern slavery }\end{array}$ & Exclusively HR norm & $\begin{array}{l}\text { Covers only type } 1 \\
\text { (HR) impacts }\end{array}$ \\
\hline $\begin{array}{c}\text { EU Conflict } \\
\text { Minerals Regulation }\end{array}$ & - & $\begin{array}{c}\text { Due diligence } \\
\text { obligations to assess } \\
\text { and address } \\
\text { violent conflicts in } \\
\text { mineral supply chains }\end{array}$ & Exclusively HR norm & - \\
\hline $\begin{array}{l}\text { French Duty of } \\
\text { Vigilance law }\end{array}$ & $\begin{array}{c}\text { Due diligence obligations } \\
\text { to assess and address } \\
\text { ENV damages }\end{array}$ & $\begin{array}{l}\text { Due diligence } \\
\text { obligations to assess } \\
\text { and address } \\
\text { HR violations and } \\
\text { ENV damages }\end{array}$ & $\begin{array}{c}\text { Integration of HR and } \\
\text { ENV issues }\end{array}$ & $\begin{array}{l}\text { Covers all severe human } \\
\text { rights and } \\
\text { environmental impacts }\end{array}$ \\
\hline $\begin{array}{l}\text { Dutch Child } \\
\text { Labor Due } \\
\text { Diligence law }\end{array}$ & - & $\begin{array}{c}\text { Due diligence } \\
\text { obligations to assess } \\
\text { and address } \\
\text { child labor }\end{array}$ & Exclusively HR norm & $\begin{array}{l}\text { Covers only type } 1 \\
\text { (HR) impacts }\end{array}$ \\
\hline $\begin{array}{l}\text { German Supply } \\
\text { Chain Due } \\
\text { Diligence Law }\end{array}$ & $\begin{array}{c}\text { Due diligence obligations } \\
\text { to assess and address } \\
\text { environment-related } \\
\text { HR violations }\end{array}$ & $\begin{array}{l}\text { Due diligence } \\
\text { obligations to assess } \\
\text { and address } \\
\text { HR violations }\end{array}$ & $\begin{array}{l}\text { Mainly HR norm, } \\
\text { ENV issues } \\
\text { partly included }\end{array}$ & $\begin{array}{c}\text { Covers mainly type } 1 \\
\text { (HR) impacts and to a } \\
\text { lesser extent type } 2 \text { and } \\
\text { type } 3 \text { impacts }\end{array}$ \\
\hline
\end{tabular}

\subsection{Implementing the French Duty of Vigilance Law: Assessing and Addressing Human Rights} and Environmental Impacts

The DV law requires companies to submit annual reports on their due diligence systems (called 'vigilance plans'), which have to be included in their financial reports and should be drawn in association with the company's stakeholders. Companies with 5000 employees within its own company and subsidiaries whose registered office is located in France and companies with at least 10,000 employees whose registered office is located in France or abroad are covered by the law. Large companies that are involved with soy and beef supply chains from Brazil such as Carrefour, Casino Group, Danone and Savencia have submitted their vigilance plans since 2018, while there are other companies working in one of these sectors that have been criticized for their non-compliance with the law 
(e.g., Lactalis) [57]. In line with the UNGPs and other international soft law norms such as the OECD Guidelines for Multinational Enterprises, the due diligence systems of companies in France shall include the assessment of environmental and human rights risks, a description of the prevention and mitigation measures to reduce or avoid risks, the evaluation of the effectiveness of adopted measures and grievance mechanisms [53]. The law foresees two types of sanctions for non-compliance with the law: (1) When a company fails to comply with its obligations, a formal notice can be sent to it at the request of any person having an interest in the matter, and if it does not take appropriate action, the competent court may subject it to a fine; (2) If severe environmental damages or human rights violations occur that could have been prevented by implementing an appropriate due diligence system, the company can be held liable and be obliged to compensate for the damage [53].

The analysis of the vigilance plans of the four above-mentioned companies reveals that all of them have prioritized certain negative impacts associated with soy and beef from Brazil, while neglecting others. With regard to environmental issues in soy and beef supply from Brazil, all companies have identified the risk of deforestation as a major concern, and Carrefour, Casino Group and Danone outlined how they respond to this risk, while Savencia's plans remained rather vague and unspecific regarding mitigation and prevention measures [58]. Other important environmental issues such as biodiversity loss, pesticide pollution or the reduction of the quality and quantity of water have only been addressed in a general manner in the plans but not specifically with regard to commodities from Brazil. In a similar vein, the companies have assessed different types of human rights in a rather selective way. The main focus of the companies has been on labor rights, while the rights of other stakeholders in Brazil that are negatively affected by the soy and beef sectors have not been discussed. As outlined above, among these rights are the right to land, health, food, water and protection from violence. In addition, the consultation with rightsholders (beside employees or trade unions) or grassroots organizations from Brazil has not been mentioned in any of the vigilance plans [57].

These findings suggest that there have been shortcomings in the due diligence systems of companies, which have selectively addressed specific salient environmental and human rights issues, instead of using more integrated approaches. More concretely, particularly those impacts have been prioritized by companies that are high on the global agenda and prominently covered in public media discourses in countries of the Global North [59], while the concerns of local communities in Brazil have largely been neglected. The inclusion or exclusion of certain impacts from due diligence systems and company reports seems to reflect asymmetric power relationships that have disfavored actors from the Global South with comparatively little voice and purchasing power.

However, the companies' perspectives on risks also suggest that cognitive factors and practical reasons have limited policy integration, as it is easier to handle impacts separately in a piecemeal fashion than to go deeper and try to handle more complex interactions between impacts in a constructive manner. With this in mind, it is also important to acknowledge the fact that it is more challenging to assess and monitor certain risks than others. In our workshop with stakeholders from Brazil in March 2020, the participants argued that the quality of available data on the rights to land, water and food is worse than, for instance, on deforestation or biodiversity loss [40]. This again sheds light on the importance of cognitive factors, such as the need to improve our knowledge and data on specific impacts, wherefore the meaningful participation of rightsholders, local stakeholders and Brazilian institutions such as the public prosecutor's offices would be of key importance.

With the aim of improving company practices and holding companies liable for any damages their supply chains cause or contribute to, as of July 2021, civil society organizations already submitted four formal notices to companies and filed four lawsuits [60]. In one of these lawsuits, environmental and human rights organizations from Brazil, Colombia and France accused Casino Group for not taking appropriate action to prevent deforestation 
and land grabs in the company's supply chains. This legal case is just one of the examples showing that the DV law has created political opportunities to build coalitions between environmental and human rights NGOs on the one hand and civil society organizations from the Global South and Global North on the other (interviews with Brazilian and European NGOs, 6 March 2020, 21 August 2019, and 10 February 2021). The plaintiffs in the lawsuit against Casino Group also reflect the close links between environmental and human rights impacts in this case, arguing: "This case is a tragic example of the interdependence between the environment and human rights, both protected by the Duty of diligence law." (Cecilia Rinaudo, general coordinator of the French NGO Notre Affaire à Tous) and "As we make clear in the complaint, the demand for beef by Casino and [its subsidiary] Pão de Açúcar brings deforestation and land grabbing and violence, and the murder of indigenous leaders when they choose to resist" (legal advisor of the Coordination of Indigenous Organizations of the Brazilian Amazon (COIAB)) [61]. While it is unclear how French Courts will decide on this and other cases, it is interesting to note that the DV law has enabled grassroots organizations from Brazil to articulate their concerns on interconnected impacts and to file lawsuits, which has created opportunities to advance policy integration 'from below'.

\section{Discussion and Conclusions}

Sustainability governance has struggled with the challenge to integrate and properly balance its social, environmental and economic pillars and to address interdependent risks equally. This study aims to contribute to such broader debates with a focus on the integration of the environment and human rights in supply chain regulations from the EU and Member States. With reference to soy and beef supply chains from Brazil, which are critical cases for both policy domains, I show that environmental and human rights impacts often co-occur, reinforcing each other (type 2 impacts) but that there can also be trade-offs between social and environmental goals (type 3 impacts). Hence, I argue that supply chain regulations that cover both policy domains and take the interaction between them into account would be particularly promising for enabling more sustainable supply chains.

However, the first experiences with the implementation of the French DV law, which encompasses both policy domains, reveal that the institutionalization of an integrated approach does not guarantee policy integration in practice. French companies involved with soy and beef supply chains from Brazil have assessed and addressed risks in a rather isolated and fragmented way. Concretely, this study points to shortcomings of internal policy integration in the company's due diligence systems, as a few environmental, respectively human rights, impacts are highlighted in the company reports, while others are deprioritized. Furthermore, environmental and human rights risks have been discussed separately by companies, and there has been a lack of attention to patterns of interaction between them, which indicates weak external policy integration.

In the following section, I discuss some of my findings regarding institutional, political and cognitive barriers for the policy integration of the environment and human rights in the governance of global supply chains.

Institutional factors: This study sheds light on a mismatch between the problem characteristics associated with global supply chains, which have been characterized by the close interconnection between environmental and human rights issues, and the institutional governance context, which is still organized in a rather fragmented and siloed way. Accordingly, most supply chain regulations adopted by the EU or Member States have selectively targeted specific environmental or human rights problems. Despite efforts to cooperate across different policy domains in the EU over the past decades, the institutional cooperation between competent authorities working in favor of environmental and human rights issues has often been weak. More research into such institutional dynamics in both policy-making and implementation processes of supply chain regulations could help to produce new insights into the enabling and hindering conditions for integrating human rights and environmental concerns in sustainability governance. 
Political factors: While previous literature has mainly focused on contestations over the enforceability of supply chain regulations, in particular over the question of whether or not they should include legal liability for companies, here I show that there have also been important contestations about the scope of the laws and the extent to which they cover environmental and human rights issues. In general, business associations and businessclose state institutions (e.g., Ministries of the Economy), as well as conservative, right-wing and liberal parties, have generally advocated for weak and narrow designs of supply chain regulations [22]. However, also many actors advocating for stringent regulations have done so with reference to a specific policy domain, i.e., either focusing on human rights or environmental issues. While staff from public institutions often just feels responsible for the institution's limited sphere of influence, many civil society organizations also specialize either on environmental or on human rights problems. The agency of actors advocating for the inclusion of environmental or human rights issues has led to the integration of both policy domains in laws to regulate supply chains, but the integration of both policy domains has not been prominently discussed in policy-making processes.

Furthermore, the analysis of the implementation of the DV law points to the importance of different interests and perspectives of actor groups in the Global North and Global South, embedded in asymmetric relations of power. In this context, the needs and interests of rightsholders and local communities affected by the (often interconnected!) negative environmental and human rights impacts of the soy and cattle sectors in Brazil have largely been neglected by French companies. The strong focus on salient sustainability problems such as Amazon deforestation is not a new phenomenon in sustainability governance [62]. In the case of supply chain regulations, closer transnational linkages between civil society organizations working on human rights and environmental issues (as observed in the French case) might help to challenge the exclusion of certain impacts from due diligence systems and related public debates and contribute to better internal and external policy integration.

Cognitive factors: My findings show that both companies and policy-makers have often approached the impacts of global supply chains in a fragmented and isolated manner. Hence, despite the fact that discourses surrounding the international agreements on environment and development and, more recently, surrounding the SDGs have emphasized the inter-related and interdependent nature of environmental and social dimensions of sustainable development, concrete governance processes are still often characterized by fragmented and selective perspectives. For instance, the French companies have usually assessed environmental and human rights risks separately, without discussing synergies and trade-offs between them. To this adds that there has been an uneven distribution of knowledge and data according to different problems, which has likely been due to specific problem characteristics (e.g., the existence or non-existence of illegal deforestation might be easier to monitor than violations of tenure rights) but also to power asymmetries linked to specific actors' interests (e.g., problems that are high on the agenda of global environmental governance attract more attention than those of vulnerable communities from places in the Global South). Such asymmetries and knowledge gaps merit more attention, to avoid that important sustainability problems are sidelined and, borrowing the words of the SDGs, to ensure that "no one will be left behind" and to "endeavour to reach the furthest behind first" [63].

However, it is important to acknowledge that policy integration is a very challenging process, not only because the environment and human rights are just some of the numerous policy domains to be integrated, but also because of practical challenges related to relevant expert knowledge, a limited sphere of influence of supply chain regulations (interacting with place-based and international governance) and the need of human actors and institutions to reduce complexity. Furthermore, there can also be trade-offs between more integrated governance approaches on the one hand and enforceability and feasibility on the other that merit further discussion, although they go beyond the scope of this paper. 
To conclude, here I argue that the increasing problematization and visibility of negative environmental and human rights impacts (and their interaction) in global supply chains are crucial, in order to create awareness and knowledge on such impacts and to search for appropriate political and institutional responses. However, this study points to important institutional, political and cognitive barriers for policy integration in supply chain regulations. I show that the negative externalities of global supply chains in the sites of production in many places (often in the Global South) are interconnected, but governance approaches to address them often follow a fragmented logic, which hinders effective problem resolution or even contributes to problematic trade-offs ('conflictive fragmentation'). While policy disintegration at the global scale might not be harmful, it can produce conflicts and environmental injustice in producing sites. More integrated approaches for regulating global supply chains and global trade would be needed to enhance 'just sustainability'.

Funding: This work was supported by the Research Council for Sustainable Development, Sweden (FORMAS, Dnr 2019-01386), the Deutsche Forschungsgemeinschaft DFG, Germany (Project: "GOVERNECT", LE 2396/4-1) and Mistra Geopolitics-Navigating towards a Secure and Sustainable Future, funded by the Swedish Foundation for Strategic Environmental Research under grant number 2016/11 \#5.

Institutional Review Board Statement: The study was conducted according to the ethical guidelines of the Deutsche Forschungsgemeinschaft DFG and the University of Osnabrück.

Informed Consent Statement: Informed consent was obtained from all subjects involved in the study.

Data Availability Statement: The data that support the findings of this study are available on request from the corresponding author. The data are not publicly available due to privacy or ethical restrictions.

Acknowledgments: I am grateful to Andrea Lenschow, Maria-Therese Gustafsson and Jan Pollex for their collaboration and our fruitful exchange on policy integration and soy and beef supply chains from Brazil.

Conflicts of Interest: The author declares no conflict of interest.

\section{References}

1. International Labour Organization (ILO). Proceedings of the International Labour Conference Report IV; Decent Work in Global Supply Chains; ILO: Geneva, Switzerland, 2016.

2. Organisation for Economic Cooperation and Development (OECD). Multinational Enterprises in the Global Economy. Heavily Debated but Hardly Measured; OECD: Paris, France, 2018. Available online: https:/ /www.oecd.org/industry/ind/MNEs-in-the-globaleconomy-policy-note.pdf (accessed on 15 July 2021).

3. Dauvergne, P. The Shadows of Consumption: Consequences for the Global Environment; MIT Press: Cambridge, MA, USA, 2010.

4. Westhoek, H.; Lesschen, J.P.; Rood, T.; Wagner, S.; De Marco, A.; Murphy-Bokern, D.; Leip, A.; van Grinsven, H.; Sutton, M.A.; Oenema, O. Food choices, health and environment: Effects of cutting Europe's meat and dairy intake. Glob. Environ. Chang. 2014, 26, 196-205. [CrossRef]

5. Pendrill, F.; Persson, U.M.; Godar, J.; Kastner, T. Deforestation Displaced: Trade in Forest-risk Commodities and the Prospects for a Global Forest Transition. Environ. Res. Lett. 2019, 14, 55003. [CrossRef]

6. Rajão, R.; Soares-Filho, B.; Nunes, F.; Börner, J.; Machado, L.; Assis, D.; Oliveira, A.; Pinto, L.; Ribeiro, V.; Rausch, L.; et al. The rotten apples of Brazil's agribusiness. Science 2020, 369, 246-248. [CrossRef]

7. Baletti, B. Saving the Amazon? Sustainable soy and the new extractivism. Environ. Plan. A 2014, 46, 5-25. [CrossRef]

8. Bombardi, L.M. Geografia do Uso de Agrotóxicos no Brasil e Conexões com a União Europeia; Universidade de São Paulo: São Paulo, Brazil, 2017.

9. Comissão Pastoral da Terra (CPT). Conflitos no Campo Brasil 2020; CPT: Goiánia, Brazil, 2021.

10. Le Billon, P.; Lujala, P. Environmental and land defenders: Global patterns and determinants of repression. Glob. Environ. Chang. 2020, 65, 102163. [CrossRef]

11. Russo Lopes, G.; Lima, M.G.B.; dos Reis, T.N. Maldevelopment revisited: Inclusiveness and social impacts of soy expansion over Brazil's Cerrado in Matopiba. World Dev. 2021, 139, 105316. [CrossRef]

12. Park, S.; Kramarz, T. (Eds.) Global Environmental Governance and the Accountability Trap; MIT Press: Cambridge, MA, USA, 2019.

13. Newig, J.; Challies, E.; Cotta, B.; Lenschow, A.; Schilling-Vacaflor, A. Governing global telecoupling toward environmental sustainability. Ecol. Soc. 2020, 25, 21. [CrossRef] 
14. Ruggie, J.G. Multinationals as global institution: Power, authority and relative autonomy. Regul. Gov. 2018, 12, 317-333. [CrossRef]

15. Dauvergne, P.; Lister, J. Big brand sustainability: Governance prospects and environmental limits. Glob. Environ. Chang. 2012, 22, 36-45. [CrossRef]

16. Schilling-Vacaflor, A.; Lenschow, A.; Challies, E.; Cotta, B.; Newig, J. Contextualizing certification and auditing: Soy certification and access of local communities to land and water in Brazil. World Dev. 2021, 140, 105281. [CrossRef]

17. Bastos Lima, M.G. Corporate Power in the Bioeconomy Transition: The Policies and Politics of Conservative Ecological Modernization in Brazil. Sustainability 2021, 13, 6952. [CrossRef]

18. Moser, C.; Leipold, S. Toward "hardened" accountability? Analyzing the European Union's hybrid transnational governance in timber and biofuel supply chains. Regul. Gov. 2021, 15, 115-132. [CrossRef]

19. Partzsch, L. Alternatives to Multilateralism: New Forms of Social and Environmental Governance; MIT Press: Cambridge, MA, USA, 2020.

20. Renckens, S. Private Governance and Public Authority: Regulating Sustainability in a Global Economy; Cambridge University Press: Cambridge, UK, 2020.

21. Partzsch, L.; Vlaskamp, M.C. Mandatory due diligence for 'conflict minerals' and illegally logged timber: Emergence and cascade of a new norm on foreign accountability. Extr. Ind. Soc. 2016, 3, 978-986. [CrossRef]

22. Schilling-Vacaflor, A.; Lenschow, A. Hardening foreign corporate accountability through mandatory due diligence in the European Union? New trends and persisting challenges. Regul. Gov. 2021. [CrossRef]

23. European Coalition for Corporate Justice (ECCJ). Evidence for Mandatory Human Rights and Environmental Due Diligence Legislation. Available online: http:/ / corporatejustice.org/wp-content/uploads/2021/03/evidence-for-mhredd-january-2021 -.pdf (accessed on 21 July 2021).

24. Agyeman, J.; Bullard, R.; Evans, B. Introduction. Joined-up thinking: Bringing together sustainability, environmental justice and equity. In Just Sustainabilities; Routledge: London, UK, 2003; Volume 30, pp. 1-16.

25. Collier, U. Energy and Environment in the European Union; Aldershot: Avebury, UK, 1994.

26. Biermann, F.; Davies, O.; Van Der Grijp, N. Environmental policy integration and the architecture of global environmental governance. Int. Environ. Agreem. Politics Law Econ. 2009, 9, 351. [CrossRef]

27. World Commission on Environment and Development (WCED). Our Common Future; Oxford University Press: Oxford, UK, 1987.

28. Lafferty, W.; Hovden, E. Environmental policy integration: Towards an analytical framework. Environ. Politics 2003, 12, 1-22. [CrossRef]

29. Jordan, A.; Lenschow, A. Environmental policy integration: A state of the art review. Environ. Policy Gov. 2010, 20, 147-158. [CrossRef]

30. Tosun, J.; Leininger, J. Governing the interlinkages between the sustainable development goals: Approaches to attain policy integration. Glob. Chall. 2017, 1, 1700036. [CrossRef]

31. United Nations Human Rights Special Procedures. Framework Principles on Human Rights and the Environment 2018. Available online: https:/ / www.ohchr.org/Documents/Issues/Environment/SREnvironment/FrameworkPrinciplesUserFriendlyVersion. pdf (accessed on 19 July 2021).

32. Siegel, K.M.; Lima, M.G.B. When international sustainability frameworks encounter domestic politics: The sustainable development goals and agri-food governance in South America. World Dev. 2020, 135, 105053. [CrossRef]

33. Merino, R.; Gustafsson, M.T. Localizing the indigenous environmental steward norm: The making of conservation and territorial rights in Peru. Environ. Sci. Policy 2021, 124, 627-634. [CrossRef]

34. Dehbi, F.; Martin-Ortega, O. Putting Planet and People First: Towards a Business and Human Rights Framework that Addresses the Impact of Corporate Activities on the Environment. Sustainability. under review.

35. Adger, W.N.; Jordan, A. (Eds.) Governing Sustainability; Cambridge University Press: Cambridge, UK, 2009.

36. Biermann, F.; Boas, I.J.C. Global adaptation governance: The case of protecting climate refugees. In Global Climate Governance Beyond 2012: Architecture, Agency and Adaptation; Biermann, F., Pattberg, F., Zelli, F., Eds.; Cambridge University Press: Cambridge, UK, 2010; pp. 255-269.

37. Nilsson, M.N.; Persson, A.S. Framework for analysing environmental policy integration. J. Environ. Policy Plan. 2003, 5, 333-359. [CrossRef]

38. Feindt, P.H. Policy-learning and environmental policy integration in the Common Agricultural Policy, 1973-2003. Public Adm. 2010, 88, 296-314. [CrossRef]

39. Dellmuth, L.; Gustafsson, M.T.; Kural, E. Global adaptation governance: Explaining the governance responses of international organizations to new issue linkages. Environ. Sci. Policy 2020, 114, 204-215.

40. Schilling-Vacaflor, A.; Lenschow, A.; Soendergaard, N.; Inoue, C.; Newig, J.; Cotta, B.; Gustafsson, M.T.; Challies, E. The Sustainability Governance of Inter-Regional Linkages: Lessons from the Brazil-Europe Soy Complex. Available online: https://www.researchgate.net/publication/351365343_The_Sustainability_Governance_of_Inter-Regional_Linkages_ Lessons_from_the_Brazil-Europe_Soy_Complex (accessed on 19 July 2021).

41. COWI; Ecofys; Milieu. Feasibility Study on Options to Step up EU Action against Deforestation; European Union: Brussels, Belgium, 2018. 
42. Silva, A.L.D.; Souza, S.A.D.; Coelho Filho, O.; Eloy, L.; Salmona, Y.B.; Passos, C.J.S. Water Appropriation on the Agricultural Frontier in Western Bahia and Its Contribution to Streamflow Reduction: Revisiting the Debate in the Brazilian Cerrado. Water 2021, 13, 1054. [CrossRef]

43. Bowman, M.S.; Soares-Filho, B.S.; Merry, F.D.; Nepstad, D.C.; Rodrigues, H.; Almeida, O.T. Persistence of cattle ranching in the Brazilian Amazon: A spatial analysis of the rationale for beef production. Land Use Policy 2012, 29, 558-568. [CrossRef]

44. Reydon, B.P.; Fernandes, V.B.; Telles, T.S. Land governance as a precondition for decreasing deforestation in the Brazilian Amazon. Land Use Policy 2020, 94, 104313. [CrossRef]

45. Pereira, J.C.; Viola, E. Catastrophic climate risk and Brazilian Amazonian politics and policies: A new research agenda. Glob. Environ. Politics 2019, 19, 93-103. [CrossRef]

46. Sparovek, G.; Reydon, B.P.; Pinto, L.F.G.; Faria, V.; Freitas, F.L.M.; Azevedo-Ramos, C.; Gardner, T.; Hamamura, C.; Rajão, R.; Cerignoni, F.; et al. Who owns Brazilian lands? Land Use Policy 2019, 87, 1-3. [CrossRef]

47. Nepstad, D.; Schwartzman, S.; Bamberger, B.; Santilli, M.; Ray, D.; Schlesinger, P.; Lefebvre, P.; Alencar, A.; Prinz, E.; Fiske, G.; et al. Inhibition of Amazon deforestation and fire by parks and indigenous lands. Conserv. Biol. 2006, 20, 65-73. [CrossRef]

48. Steward, C. From colonization to 'environmental soy': A case study of environmental and socio-economic valuation in the Amazon soy frontier. Agric. Hum. Values 2007, 24, 107-122. [CrossRef]

49. Schleifer, P. Orchestrating sustainability: The case of European Union biofuel governance. Regul. Gov. 2013, 7, 533-546. [CrossRef]

50. Regulation (EU) No 995/2010 of the European Parliament and of the Council of 20 October 2010 Laying down the Obligations of Operators Who Place Timber and Timber Products on the Market. Available online: https:/ / eur-lex.europa.eu/legal-content/ EN/ALL/?uri=CELEX:32010R0995 (accessed on 25 July 2021).

51. Ituarte-Lima, C.; Dupraz-Ardiot, A.; McDermott, C.L. Incorporating international biodiversity law principles and rights perspective into the European Union Timber Regulation. Int. Environ. Agreem. Politics Law Econ. 2019, 19, 255-272. [CrossRef]

52. Rivera, H.C. National Action Plans on Business and Human Rights: Progress or Mirage? Bus. Hum. Rights J. 2019, 4, 213-237. [CrossRef]

53. LOI no 2017-399 du 27 mars 2017 Relative au Devoir de Vigilance des Sociétés Mères et des Entreprises Donneuses D’ordre. Available online: https:/ / www.legifrance.gouv.fr/download/pdf?id=9aawcYcwvkntYs2UUCMWL4iX_erjixoTD_Jy3AVXRFk= (accessed on 25 July 2021).

54. Deutscher Bundestag. Gesetzentwurf der Bundesregierung Entwurf Eines Gesetzes über die Unternehmerischen Sorgfaltspflichten in Lieferketten. Drucksache 19/28649. Available online: https:/ / www.bundestag.de/dokumente/textarchiv/2021 / kw23-de-lieferkettengesetz-845608 (accessed on 25 July 2021).

55. Bund für Umwelt und Naturschutz Deutschland, E.V. (BUND). Verwässertes Lieferkettengesetz: Nächste Bundesregierung muss beim Umweltschutz Nachbessern, 11 June 2021. Available online: https: / / www.bund.net/service/presse/pressemitteilungen/ detail/news/kommentar-zum-verwaesserten-lieferkettengesetz-naechste-bundesregierung-muss-beim-umweltschutznachbessern/ (accessed on 15 July 2021).

56. Deutscher Bundestag. Änderungsantrag der Fraktion BÜNDNIS 90/DIE GRÜNEN zu der Zweiten Beratung des Gesetzentwurfs der Bundesregierung-Drucksachen 19/28649, 19/29592, 19/30505-Entwurf für ein Gesetz über die unternehmerischen Sorgfaltspflichten in Lieferketten. Drucksache 19/30546. Available online: https:/ /dserver.bundestag.de/btd/19/305/1930546 .pdf (accessed on 20 July 2021).

57. Schilling-Vacaflor, A.; Gustafsson, M.T. Foreign Corporate Accountability: Does Mandatory Due Diligence in France Contribute to Address Adverse Impacts of Commodity Chains from Brazil? In Proceedings of the ICPP5 Conference, Barcelona, Spain, 5 July 2021.

58. Sherpa; Terre Solidaire; Business \& Human Rights Resource Center. Vigilance Plans. Available online: https://vigilance-plan.org (accessed on 21 July 2021).

59. Mempel, F.; Corbera, E. Framing the frontier-Tracing issues related to soybean expansion in transnational public spheres. Glob. Environ. Chang. 2021, 69, 102308. [CrossRef]

60. Business \& Human Rights Resource Centre. France's Duty of Vigilance Law. Available online: https://www.businesshumanrights.org/en/latest-news/frances-duty-of-vigilance-law/ (accessed on 21 July 2021).

61. Mighty Earth. Amazon Indigenous Communities and International NGOs sue Supermarket Giant Casino/Pão de Açúcar/Éxito over Deforestation and Human Rights Violations. Available online: https://www.mightyearth.org/2021/03/03/amazonindigenous-communities-and-international-ngos-sue-supermarket-giant-casino-pao-de-acucar-exito-over-deforestation-andhuman-rights-violations / (accessed on 21 July 2021).

62. Gardner, T.A.; Benzie, M.; Börner, J.; Dawkins, E.; Fick, S.; Garrett, R.; Godar, J.; Grimard, A.; Lake, S.; Larsen, R.K.; et al. Transparency and sustainability in global commodity supply chains. World Dev. 2019, 121, 163-177. [CrossRef]

63. United Nations General Assembly. Transforming Our World: The 2030 Agenda for Sustainable Development. Resolution adopted by the General Assembly on 25 September 2015. Available online: https:/ /www.un.org/ga/search/view_doc.asp?symbol=A/ RES/70/1\&Lang=E (accessed on 20 July 2021). 